Volume 3

Issue 1 The Syriac Galen Palimpsest

Article 12

5-9-2019

Compilation, Collation and Correction in the Time of Encyclopedism: The Case of UPenn LJS 55

Nathalie Lacarrière

University of Pennsylvania, nlacar@sas.upenn.edu 


\title{
Compilation, Collation and Correction in the Time of Encyclopedism: The Case of UPenn LJS 55
}

\begin{abstract}
This article looks into UPenn LJS 55, a French thirteenth century manuscript composed of four different works that exemplify the Encyclopedic drive of the time: Gossuin de Metz's Image del monde, Honorius Augustodunensis' Elucidarium, in an anonymous French prose version called Lucidaire, a Moralités des Philosophes in prose and an unidentified fourth text. By analyzing the collation of the manuscript, this article suggests that two of the eight quires that are comprised in the manuscript are incomplete, leading to the creation of a new collation model and the identification of the fourth piece as Aldobrandino da Siena's Régime du corps. Finally, the analysis of the corrections in Metz's text will help classify the Image del Monde in LJS 55 as verse, not prose.
\end{abstract}

\section{Keywords}

Gossuin de Metz, Image du Monde, Lucidaire, Moralités des philosophes, Aldobrandino da Siena, Régime du corps, Encyclopedism, vernacular, corrections 


\section{MANUSCRIPT STUDIES}

A Journal of the Schoenberg Institute for Manuscript Studies

VOLUME 3, NUMBER 1

(Spring 2018)

Manuscript Studies (ISSN 2381-5329) is published semiannually

by the University of Pennsylvania Press

The Schoenberg Institute
for Manuscript Studies
University of Pennsyivania Libraries 


\section{MANUSCRIPT STUDIES}

A Journal of the Schoenberg Institute for Manuscript Studies

VOLUME 3, N UMBER 1

Special Issue:

The Syriac Galen Palimpsest

Editors: William Noel and Ralph M. Rosen

\section{Articles}

The Syriac Galen Palimpsest Project: An Introduction

William Noel and Ralph M. Rosen

Pulling It All Together: Managing the Syriac Galen

Palimpsest Project

Michael B. Toth

The Codicology and Conservation of the Syriac

Galen Palimpsest

Abigail B. Quandt and Renée C. Wolcott

Spectral Imaging Methods Applied to the Syriac

Galen Palimpsest

Roger L. Easton, Jr., Keith T. Knox, William A. Christens-Barry, And Ken Boydston

The Galen Palimpsest and the Modest Ambitions of the

Digital Data Set

Doug EMERY

The Syriac Galen Palimpsest: A Tale of Two Texts

Naima Afif, Siam Bhayro, Grigory Kessel, Peter E. Pormann,

William I. Sellers, and Natalia Smelova 
iv | Journal for Manuscript Studies

Analyzing Images, Editing Texts: The Manchester Project

Naima Afif, Siam Bhayro, Peter E. Pormann, William I. Sellers,

and Natalia Smelova

The Textual Interest of the Syriac Versions of Galen's Simples

Irene Calà, Jimmy Daccache, and Robert Hawley 186

\section{Annotations}

Of Scribes and Scripts: Citizen Science and the Cairo Geniza

Laura Newman Eckstein

Preserving Endangered Archives in Jerba, Tunisia:

The al-Bāsī Family Library Pilot Project

Ali Boujdidi And Paul M. Love

The Intricacies of Capturing the Holdings of a Mosque

Library in Yemen: The Library of the Shrine of Imām alHādī, Șa da

Sabine Schmidtke

Compilation, Collation and Correction in the Time of Encyclopedism: The Case of UPenn LJS 55

Nathalie Lacarrière

Mapping Manuscript Migrations: Digging into Data for the History and Provenance of Medieval and Renaissance

Manuscripts

Toby Burrows, Eero Hyvönen, Lynn Ransom, and Hanno Wijsman

\section{Reviews}

Ahmmad 'Abd al-Bāsiț. Catalogue of the Private Collections of

Manuscripts in the Egyptian National Library

ELIAS G. SABA 
David T. Gura. A Descriptive Catalogue of the Medieval and Renaissance Manuscripts of the University of Notre Dame and Saint Mary's College

Lisa Fagin Davis

Christopher De Hamel. Meetings with

Remarkable Manuscripts

Daniel Traister 
Lacarrière: Compilation, Collation and Correction in the Time of Encyclopedis 


\title{
Compilation, Collation, and Correction in the Time of Encyclopedism The Case of UPenn LJS 55
}

\author{
NATHALIE LACARRIÈRE \\ University of Pennsylvania
}

$\mathrm{B}$

y combining astrological, theological, philosophical, and medical pieces in one volume, the University of Pennsylvania's LJS 55 manuscript exemplifies in many ways the encyclopedism prevalent in thirteenth-century Europe. ${ }^{1}$ This French manuscript dating from the late 1200s is composed of four different works whose diversity testifies to a certain drive to compile wide-ranging knowledge: the eponymous Image del Monde, ${ }^{2}$ originally composed around 1246 by Gossuin (or Gautier) de Metz; the Lucidaire, in an anonymous thirteenth-century prose version and vernacular translation of Honorius Augustodunensis's eleventh-century Latin text; the Moralités des Philosophes in Old French prose; and finally, a single leaf belonging to what at first appeared to be an unidentified obstetrical work.

1 On the question of encyclopedic writing and the compilation of knowledge in the Middle Ages, see Mary Franklin-Brown, Reading the Word: Encyclopedic Writing in the Scholastic Age (Chicago: University of Chicago Press, 2012), or Jason König and Greg Woolf, eds., Encyclopaedism from Antiquity to the Renaissance (Cambridge: Cambridge University Press, 2013).

2 The first piece indeed lends its name to the entire LJS 55 manuscript, which is also known as Image del Monde. A more standardized version of this title, Image du Monde, will also be used in this article when not applied to LJS 55. 
With few illuminations, except a series of diagrams for the Image del Monde, several decorated initials, and red rubrications for chapter headings and titles, LJS 55 was most likely not meant to be aesthetically admired but instead probably served as a text of study, as evidenced by the many corrections that riddle the manuscript. The coarse quality of the parchment and the irregular semi-textualis hands that compose the manuscript also point to the didactic and pedagogical aim of the volume. ${ }^{3}$

If the corrections and annotations are an initial point of interest for LJS 55 , it is the incongruities concerning its collation that led to a series of findings concerning the manuscript, including the identification of the fourth piece and the recategorization of the Image del Monde as verse and not prose. ${ }^{4}$

\section{On the Collation of the Manuscript}

The collation model suggested by the catalog description of the manuscript was aided by the clear signature markings: not only are the leaves numbered in pencil by a modern hand in each upper-right-hand recto, but two contemporary hands also give clues as to the order and sequence of the quires. On the last leaf of each of quires 1 through 7-out of the eight that compose LJS 55-two annotations can be found on the lower-right-hand verso corner (fig. 1). The first, to the left, indicates a number-from 1 to 7, corresponding to the quires in question-followed by a catchword. This device was probably intended to facilitate the binding or rebinding of the manuscript and ensure the proper ordering of the eight total quires. The second annotation, in a slightly more faded ink, shows a roman numeral. The first

3 Although her work focuses on Gossuin de Metz, Katherine Brown argues that the use of the vernacular shifts the traditional transmission of knowledge, from Latin works seeking a clerkly audience, to a vernacular writing that encompasses a wider audience. Her conclusion could be applied to all compendia similar to LJS 55 and thus underlines the pedagogical nature of such manuscripts. Katherine A. Brown, "The Vernacular Universe: Gossuin de Metz's Image du Monde, Translatio Studii, and Vernacular Narrative," Viator 44, no. 2 (2013): 137-58.

4 I am indebted to Amey Hutchins, William Noel, Dot Porter, and Nicholas Herman for their guiding and help in this endeavor. 


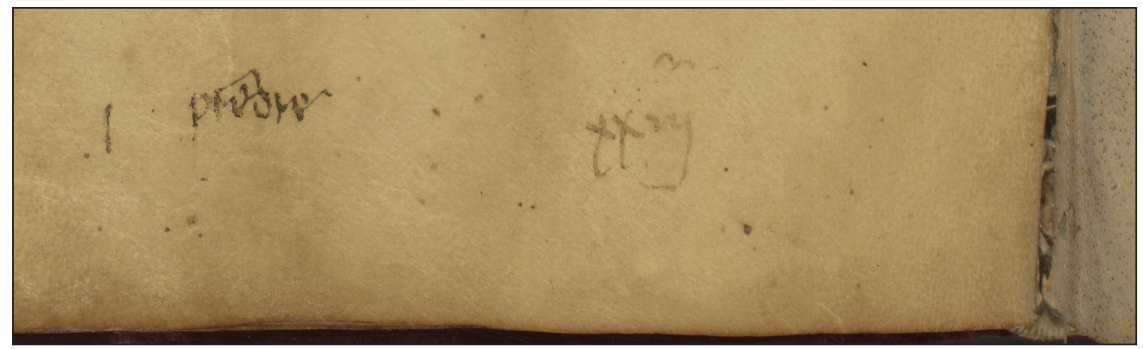

FIGURE 1. University of Pennsylvania Libraries, LJS 55, folio 8v. Detail of a catchword and signature markings.

quire of the manuscript has the number xxiij, the second xxiiij, and so on, until the seventh gathering, when the series is complete with the number xxviiij.

The presence of such annotations, theoretically preceding all others, given the color of the ink, suggests that LJS 55 was originally part of a larger manuscript and that the eight quires that the University of Pennsylvania possesses were in fact the last of the entire volume. ${ }^{5}$ This should come as no surprise in the context of encyclopedic pursuit. and a quick search on the Bibliothèque nationale de France's database, Gallica, shows that many of the manuscripts that contained the Image del Monde, the Lucidaire, and the Moralités were encompassed in large volumes. We can surmise that the intention of the whole manuscript was perhaps to assemble as many theological and scientific —or what we would call nowadays, pseudoscientificworks in one volume.

The collation model indicated by the foliation, among other features, was as follows: $1-5^{8} 6^{2} 7^{8} 8^{2}$. Yet the regularity shown in quires 1 through 5 and 7, with gatherings of eight leaves, seems oddly upset by the sixth and eighth quires, which are composed of a single bifolium. Could it be that this was not intentional but, on the contrary, the result of missing leaves? If they were, they would not be the outer leaves, since the catchwords clearly

5 As demonstrated at the end of this article, the last leaf of the eighth quire shows that the last work is incomplete, the copying of which was abruptly interrupted, thus suggesting no other work was to follow it. 


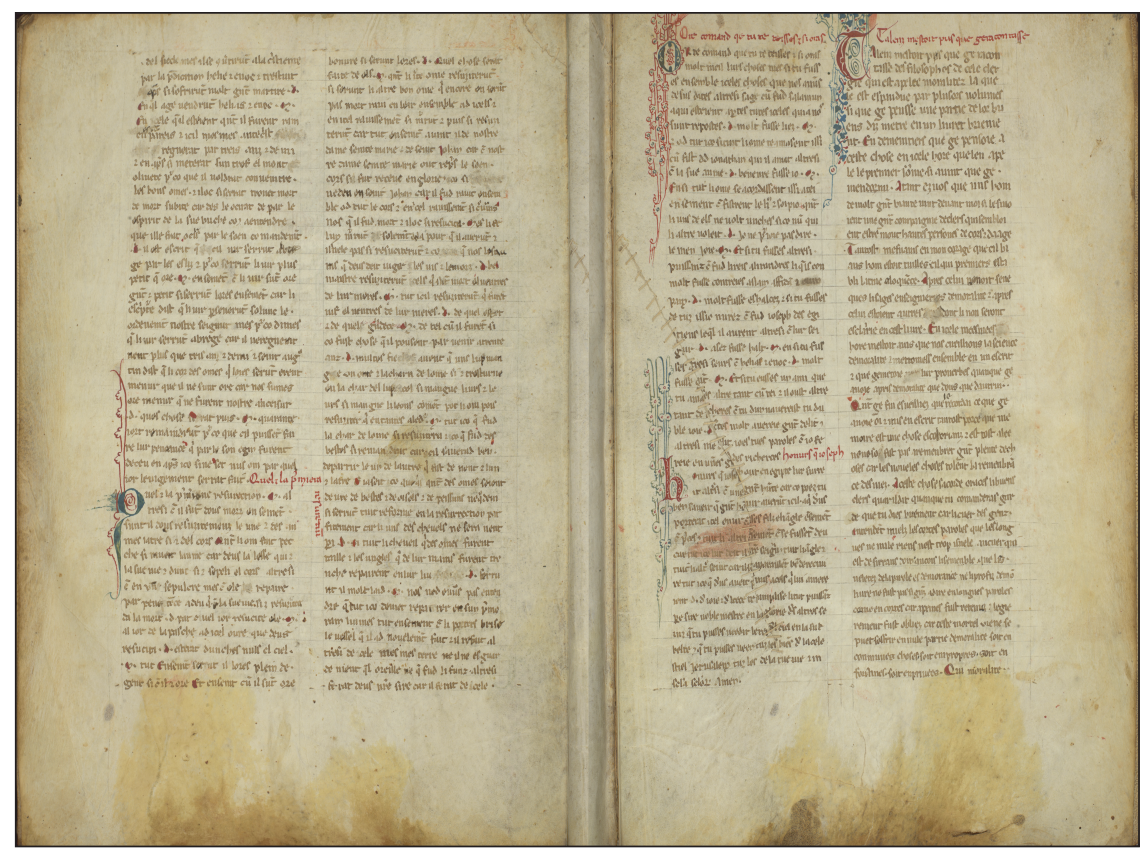

FIGURE 2. University of Pennsylvania Libraries, LJS 55, folios 41v and 42r. Facing folios $41 \mathrm{v}$ and $42 \mathrm{r}$ reveal missing leaves in quire 6.

indicate a continuation between one quire and the next. However, and as is often the case for missing leaves in medieval manuscripts, it is possible that the three missing bifolia for quires 6 and 8 had come apart at some point in time and become lost.

The first quire in question contains both the Lucidaire and the Moralités des Philosophes, the former ending at the bottom of the first column on folio $42 \mathrm{r}$, and the latter beginning subsequently at the top of the second column (fig. 2). The examination of folios $41 \mathrm{v}$ and $42 \mathrm{r}$ followed by a cursory transcription of the last few lines of folio 41v are key in determining if the quire is incomplete, as it was not immediately apparent whether or not some leaves are missing between the two. Comparing the resulting transcription with other extant manuscripts of the Lucidaire, in its prose and vernacular Old French version, confirms that the text as it stands in LJS 55 is incomplete.

The last three lines of folio 41v, at the bottom of the second column, read "tresi de cele mesmes terre ne il ne esguar / de nient q(ue)l oreille ne q(ui) fud 
li funz . altresi / ferat deus n(ost)re sire car il ferat de cele." At the top of folio $42 \mathrm{r}$, the text reads, in red rubrication: "Ore comand qe tu te teisses (et) si oras." However, in the manuscript used for comparison, BL MS 28260 (fol. 78r), the former sentence continues as follows: "au-tre de cele meme t(er)re (et) il ne garde -e quex fu loroille ne q(ue)x fu li fonz. autresi refara n(ost)re sire decele meme t(er)re cors qui ne sera pas se(m)blanz a celui cors -e ne sera pas, "6 thus confirming that folio $42 \mathrm{r}$ was not intended to immediately follow folio 41v in LJS 55. Further comparison shows that many pages of the Lucidaire found at the British Library are indeed missing and could likely correspond to the three leaves needed to complete the quire.

\section{Identifying the Fourth Text}

The second irregularity concerning the collation model brings us to the identification of the fourth text of the manuscript. Following the same hypothesis as with quire 6 , I surmised that the missing leaves in quire 8 must have been the middle ones. To verify this, it became necessary to identify the fourth text in LJS 55.

Quire 8 is composed of one bifolium that is numbered in pencil as folios 51 and 52. On folio 51v, the previous text, Les Moralités des Philosophes, ends right at the bottom of the second column. If any leaves were missing, we would hence be missing the beginning of the next and final work. A brief survey of the last folio indicates that the text in question might be obstetri$\mathrm{cal}$, or at least medical, in nature. The author seemed to provide recipes and advice to pregnant women and women who had just given birth. Just as with quire 6, the transcription of a few lines allowed for a quick identification of the work.

By entering this transcription into an internet search engine, it was possible to match it with other manuscripts at the Bibliothèque nationale de France (BNF) in Paris. BNF MS 2021 provided a perfect comparison with

6 British Library MS 28260, fol. 78r. The italics (my emphasis) point to the part of the sentence that should be the continuation to fol. $41 \mathrm{v}$ in LJS 55. 
our folio and enabled me to make the identification. The last folio in LJS 55 corresponds in fact with the eighteenth chapter in Aldobrandino da Siena's Le Régime du corps, also known as De regimine sanitates, written in $1256 .{ }^{7}$ Aldobrandino da Siena, an Italian doctor who lived in the city of Troyes, France, from 1277 to his death, wrote this dietetic text in Old French, drawing largely on the knowledge vehiculated by canonical authors such as Avicenna, Ali Abbas, Rhazes, and Aristotle. The medical nature of the work as well as its date seem to fit well with the overall encyclopedic and all-encompassing nature of the manuscript.

The comparison with BNF MS 2021 allows us to proportionally determine if eighteen chapters could correspond to the three missing leaves of the quire. In the BNF manuscript, Chapter XVIII spans approximately 1.6 pages, whereas in LJS 55 it occupies about 40 percent of the page (or a ratio of 0.4 ). Now, the previous chapters I through XVII take up twenty-six folia in the French manuscript from the BNF. A simple cross-multiplication confirms, if not with exact precision, at least with near-certainty that the missing chapter would have taken up approximately 6.5 folia, corresponding to the missing quire leaves.

Interestingly enough, the Régime $d u$ corps would have been incomplete even if the quire had been whole. It appears that the text trails off, midsentence, toward the middle of the second column in folio $52 \mathrm{v}$ (fig. 3). Whether the clerk left this work incomplete on purpose or not, or whether the copying of the manuscript stopped at the instruction of the patron, is uncertain. What we do know is that LJS 55 presents Chapter XVIII in its entirety and part of Chapter XIX on folios 52r and 52v.

Using VisColl, a tool capable of making models of collation and visualizing them, the collation for the whole manuscript appears quite clearly. The data-modeling tool allows us to recreate and visually represent the

7 The manuscript was transcribed and published in 1911 and provided an invaluable source for determining the nature of the last text. Aldobrandino da Siena, Régime du corps de maitre Aldebrandin de Sienne: Texte français du XIIIe siècle publié pour la première fois d'après les manuscrits de la Bibliothèque nationale et de la bibliothèque de l'Arsenal, ed. Louis Landouzy and Roger Pépin (Paris: Champion, 1911). 


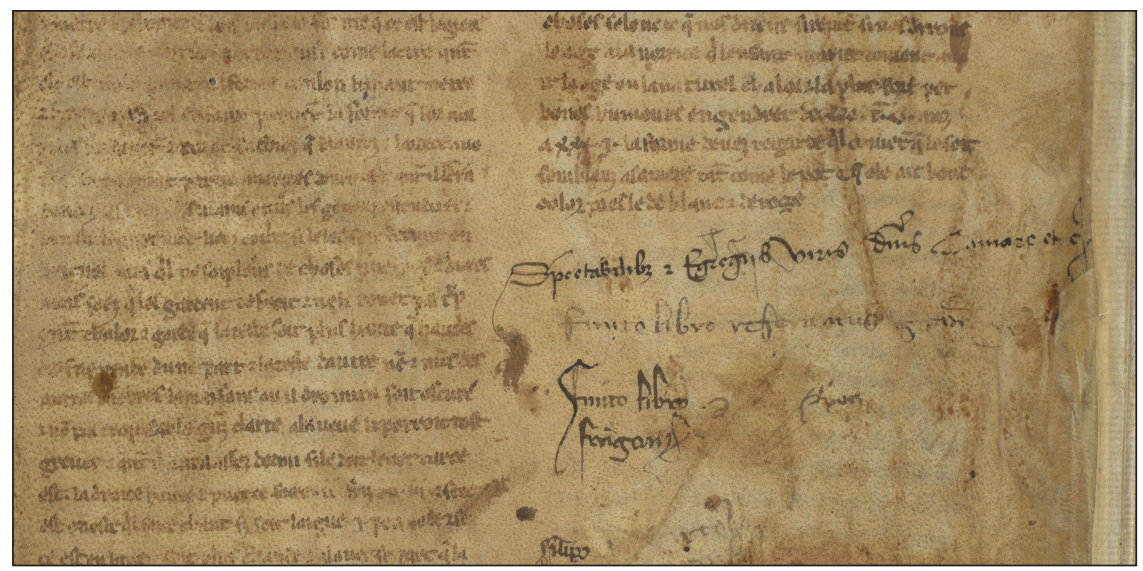

FIGURE 3. University of Pennsylvania Libraries, LJS 55, folio 52v. The manuscript comes to an abrupt stop in the middle of the second column, mid-sentence.

missing folia (fig. 4), which helps our understanding of the manuscript as a whole. $^{8}$

Overall, the identification of the fourth text as a medical work contributes to the standing of LJS 55 as a complete and varied encyclopedic compilation of wide-ranging works, from astronomical to philosophical and physiological. It also ascertains the underlying coherence and regularity of the manuscript, which, despite seeming irregular at first glance, is actually composed of eight quires of eight leaves each. In light of this, I would propose the following collation model for LJS $55: 1-5^{8} 6^{8-(2-7)} 7^{8} 8^{8-(2-7)}$.

\section{Between Verse and Prose: Image del Monde}

As has previously been established, LJS 55's composition and collation are crucial in understanding the creation of a compilation that fits into the European, thirteenth-century fashion of encyclopedias. If we turn to the

8 This visualization was created using VisColl (https://github.com/leoba/VisColl) on 14 June 2017. 


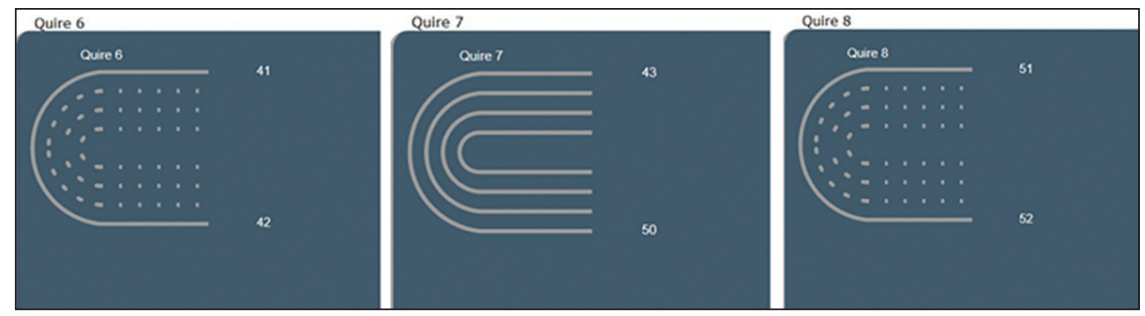

FIGURE 4. Collation model for quires 6, 7 and 8 visually represented using VisColl.

annotations, this erudite endeavor is confirmed through the physical traces left by those contemporary readers who, in the late thirteenth or early fourteenth centuries, diligently corrected the spelling, grammar, and sometimes even the content of the manuscript. ${ }^{9}$

A striking feature of the first text, Image del Monde, is the systematic correction of the rubrication by what appears to be a somewhat contemporary hand. Although there is no certainty, the similarities in hand (semitextualis) and in spelling-although the corrections sometimes lack coherence is this regard-suggest that the corrections happened sometime at the beginning of the fourteenth century.

Starting with the fifth rubrication that we encounter, which corresponds to the first chapter of the text after the prologue, the existing title is crossed out, a reference mark resembling the roman numeral I is inserted, and a new title is inscribed in the margin. Figure 5 exemplifies this process for the first title. In this instance, "Quant dez fist le mo(n)de p(re)merz" is replaced by "de la puissa(n)ce di deu." Although the two titles differ, both represent the same content, and in general, there is little to no semantic gap between the original and the corrected titles. This appears more clearly in the following title change, through which "des forma home asabla(n)ce" becomes "purq(ue) des forma home asasebla(n)ce” (fol. 2r).

9 It is unclear if several hands were responsible for the annotations of the manuscript. However, I would argue that given the difference in intent as well as the physical dissimilarities (ink, hand) between the different types of corrections, two or more hands had a role in annotating LJS 55. 


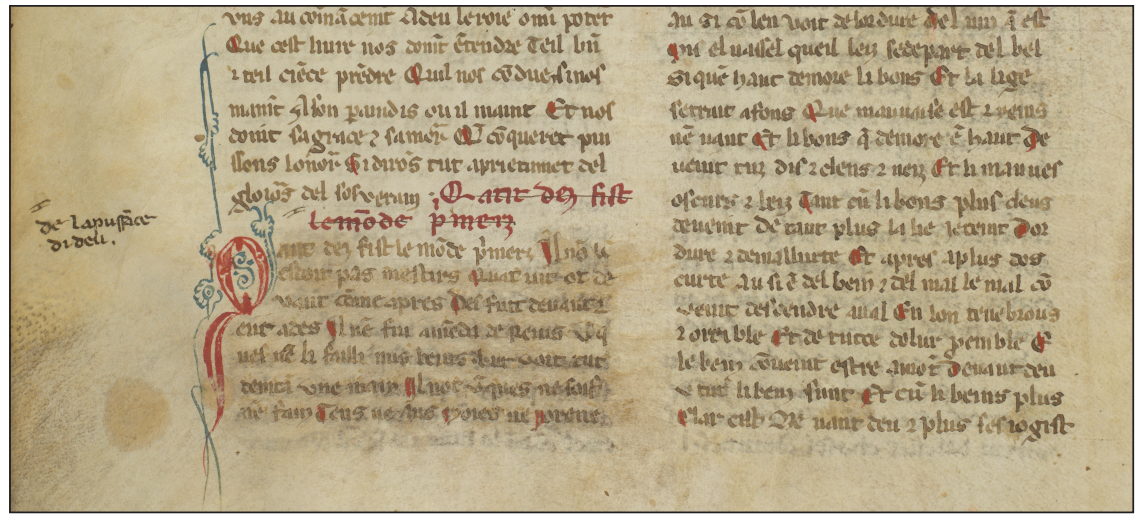

FIGURE 5. University of Pennsylvania Libraries, LJS 55, folio 1v. The rubrication is crossed out and supplanted by another title in the margins.

If the new titles do not add any significant meaning to the text that follows or to our understanding of the title itself, we may ask what the purpose of such corrections is. To answer this question, we must take a closer look at the history and evolution of the Image $d u$ Monde. Originally written in verse around 1246, the Image $d u$ Monde had three subsequent versions, resulting in three different verse compositions-in which several thousand lines were supplemented, with additional subchapters and a bipartite division instead of the original tripartite one-and a prose version. The date for the latter is unknown and diverges according to different hypotheses-between 1246, immediately following the first verse version, and 1280 - but it is recognized that the model for the prose was the first verse composition, mainly because it follows the division into three parts and it faithfully reproduces the content of the first version.

Now when taking a closer look at the new titles, one realizes that they correspond to the prose version of the Image du Monde. Yet that results in a new question: what did the previous titles reflect, and where did they come from?

LJS 55 is categorized as prose, in great part because it looks like prose on the page. Written in two columns, the text runs continuously, with punctuation marks interspersed and red-filled capitals throughout. However, a close inspection reveals some key, albeit slight, differences with the prose version. 


\begin{tabular}{|c|c|c|}
\hline BNF Ms fr. 2021 & LJS 55 & BNF Ms NAF 6883 \\
\hline (vers) & (?) & (prose) \\
\hline $\begin{array}{l}\text { Ki bien veut ente(n)dre cest livre (et) } \\
\text { savoir (con)ment il doit vivre (et) } \\
\text { apprendre tele clergie } \\
\text { d ont mi(eus) velra tote se vie } \\
\text { s i lise tot ap(er)tement } \\
\text { (et) ap(re)s ordeneement } \\
\text { s il kil ne lise viens avant } \\
\text { s il ne(n)te(n)t tou ki est deva(n)t } \\
\text { e nsi porra le livre entendre } \\
\text { q' aut(r)eme(n)t nel puet n'ente(n)dre }\end{array}$ & $\begin{array}{l}\text { Que bien veit e(n)tedre cest livre } \\
\text { (et) savoir co(n)me(n) il deit vivre } \\
\text { Eapre(n)dre celle clergie du(n)t } \\
\text { meaus vaudra tute sa vie. Et } \\
\text { apres ordenem(en)t si q(ue) il } \\
\text { ne(n) lise rem(e)s ava(n)t sil ne(n) } \\
\text { ten(i)t q(ue) est devant En si } \\
\text { purra livre apre(n)dre } \\
\text { Qu(a)t(r)em(en)t nel poit vus } \\
\text { e(n)te(n)dre. }\end{array}$ & $\begin{array}{l}\text { (Q)ui bien veult savoir (et) } \\
\text { ente(n)dre cest livre pour savoir } \\
\text { (et) aprandre (con)mant il doit } \\
\text { vivre. (et) soi contenir en cest } \\
\text { siecle. dont il vaudra mieuz touz } \\
\text { les iourz de la vie. Si lise tout } \\
\text { premierement. (et) tout } \\
\text { ordeneement. Si quil ne lise rien } \\
\text { avant. devant ce qui entendra } \\
\text { bien ce qui est devant. Et emfi } \\
\text { porra savoir (et) entendre cest lui. } \\
\text { Ore donques qui vieult entendre } \\
\text { acest (con)mandement... }\end{array}$ \\
\hline
\end{tabular}

FIGURE 6. Comparison of three different transcriptions, showing LJS 55 to be closer to the verse composition of BNF MS fr. 2021.

Yet again, the comparison with other contemporary, late thirteenth-century manuscripts, along with the transcription of a few lines, helps in determining what we are dealing with. Incidentally, the same BNF manuscript that provided the Régime du corps also contains the Image $d u$ Monde and clearly presents itself as a verse version of the text. The BNF also holds an Image $d u$ Monde in prose, MS NAF 6883, which is essential to the comparative process.

Because of its introductory position and the very recognizable characteristics of the prologue, this was the section selected in order to proceed with the comparison of all three manuscripts (fig. 6). Although a more systematic methodology would allow us to validate these findings more definitively, the result of the comparison of these three versions leads us to affirm that the Image del Monde as it appears in LJS 55 resembles more closely the verse composition than the prose one. We can therefore conclude either that the scribe was copying a verse version and decided to write it continuously on the page, like prose, or that he was copying from an existing verse composition looking like prose. The medieval reader of LJS 55, thinking that the text was prose, supplanted the rubrications found in the prose composition, without realizing where the discrepancy came from.

What conclusions can we draw from the recategorization of Image del Monde as verse and not prose? First, it evidently underlines the pedagogical 
nature of this manuscript. Far from being destined to be a beautiful showpiece like other manuscripts of the Middle Ages, LJS 55 was meant to be read, annotated, and assimilated. By using a verse version but writing it as prose, the scribe gained a substantial amount of space, and thus paper, underscoring the economical implications of this decision.

Although misleading to readers, both medieval and modern, the setting of the text on the page is just one of the many indications of its use in the late thirteenth century. Just like the annotations and corrections show us, this was a manuscript to be studied in true scholastic fashion. In the end, it shows that the didactic aim of the century of encyclopedism was mirrored in the will to create and copy compilations such as LJS 55. 